\title{
Improving the fatty acid profile of dairy cow milk by combining grazing with feeding of total mixed ration
}

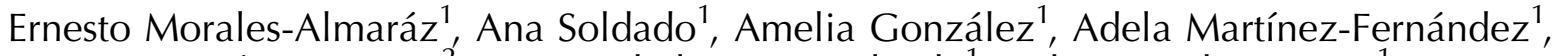 \\ Ignacio Domínguez-Vara ${ }^{2}$, Begoña de la Roza-Delgado ${ }^{1}$ and Fernando Vicente ${ }^{1 *}$ \\ ${ }^{1}$ Regional Institute for Agro-Food Research and Development (SERIDA), E-33300, Villaviciosa (Asturias), Spain
${ }^{2}$ FMVZ-UAEM, Autonomous University of State of México, 50090 Toluca, Mexico
}

Received 29 May 2009; accepted for publication 22 December 2009; first published online 3 March 2010

\begin{abstract}
Grazing cows could produce milk with a higher proportion of polyunsaturated fatty acids, which is beneficial to human health, compared with non-grazing cows, though grazing alone could compromise milk production. Under oceanic climate conditions, a study involving 15 dairy cows, fed total mixed ration (TMR) ad libitum in combination with different grazing times of $12 \mathrm{~h}$ (TMR12), $6 \mathrm{~h}$ (TMR06) and zero grazing time (TMR00) with the aim to evaluate different strategies on the fatty acids profile of milk and milk production. No differences were seen between the treatments with respect to milk yield $(34.4 \pm 6.3 \mathrm{~kg} / \mathrm{d})$ or milk protein content $(30 \cdot 4 \pm 1 \cdot 8 \mathrm{~g} / \mathrm{kg})$. The milk produced by the TMR12 cows had less total fat $(36 \cdot 2 \mathrm{vs} .38 \cdot 2 \mathrm{~g} / \mathrm{kg})$ and saturated fatty acid (FA, 69.39 vs. $71.44 \mathrm{~g} / 100 \mathrm{~g}$ FA) than that produced by the TMR00 cows. The concentration of vaccenic acid in the TMR06 and TMR12 milk was twice that of the TMR00 milk (4.22, 4.09 and $2 \cdot 26 \mathrm{~g} / 100 \mathrm{~g}$ FA respectively). Linear increases in conjugated linoleic (CLA) and linolenic acids were observed with increasing grazing time. Pasture was an important source of FA especially C18:3 for TMR06 and TMR12 cows. Under oceanic climatic conditions, the grazing of dairy cows as a complement to feeding with TMR can improve the FA profile of milk and increase its CLA content.
\end{abstract}

Keywords: Conjugated linoleic acid, grazing time, milk fatty acid, dairy cow.

Saturated fatty acids (SFA) have been associated with heart disease; the ingestion of milk fat, with its high proportion of SFA (70-75\%), has therefore been a subject of concern. About $2 \%$ of milk fatty acids (FA) are, however, polyunsaturated (PUFA) (Elgersma et al. 2006), which could help maintain human health. Different studies have examined the role of nutrition in lactating cows as a means of modifying the FA profile of milk, i.e., reducing the proportion of SFA and increasing that of PUFA, mainly conjugated linoleic acid (CLA). Diet plays an important role in determining the degree of unsaturation of cow milk fat. Long chain FA are particularly affected since ruminants cannot synthesize them; the diet is therefore the only source (Elgersma et al. 2005). It is well known that, compared with non-grazing cows, grazing cows produce milk with a FA profile favourable to human health, with higher proportions of CLA, vaccenic (VA) and linoleic acids (Dewhurst et al. 2006). This invests fresh forage with

*For correspondence; e-mail: fvicente@serida.org added value and highlights grazing as a worthwhile natural production system. However, grazing alone cannot meet the nutritional requirements of high production dairy cows, particularly in early lactation, and supplementation is required to provide the energy required for an animal's genetic potential to be fully reached. Supplementation with total mixed ration (TMR) could help produce high yields of milk with enhanced protein and fat contents, with the grazing component allowing a better milk FA profile to be achieved, moreover, the economic cost of this production system could be lower. The effects of feeding TMR and pasture diets have been previously reported (Fontaneli et al. 2005), and associate grazing with a smaller dry matter intake and lower milk production compared with intensive systems. In addition, the effects of pasture feeding and TMR feeding systems on milk FA composition have been reported by several authors (Kay et al. 2005; Vibart et al. 2008). However, the intensity of grazing that can be allowed for achieving a better FA profile without compromising milk yield has not been checked in areas with an oceanic climate. This is found along European 
Table 1. Composition ( $\%$ DM) of the total mixed ration (TMR) and concentrates

\begin{tabular}{|c|c|c|c|}
\hline & & & cates \\
\hline & TMR & A & B \\
\hline Maize silage & $43 \cdot 6$ & & \\
\hline Faba bean silage & $22 \cdot 7$ & & \\
\hline Barley straw & $6 \cdot 8$ & & \\
\hline Maize grain & & $15 \cdot 1$ & $56 \cdot 4$ \\
\hline Barley grain & $1 \cdot 9$ & $38 \cdot 0$ & \\
\hline Rye grain & & $10 \cdot 0$ & \\
\hline Wheat grain & & & $7 \cdot 7$ \\
\hline Roasted soybean & $6 \cdot 1$ & $18 \cdot 3$ & $7 \cdot 7$ \\
\hline Roasted soybean (By-pass) & $1 \cdot 4$ & & $25 \cdot 6$ \\
\hline Sunflowers seed meal & $2 \cdot 6$ & $10 \cdot 0$ & \\
\hline Maize flakes & $7 \cdot 5$ & & \\
\hline Cotton seed meal & $0 \cdot 8$ & & \\
\hline Beet pulp & $5 \cdot 2$ & & \\
\hline Molasses & & $3 \cdot 0$ & $1 \cdot 0$ \\
\hline Salts of vegetal FA by-pass & $0 \cdot 6$ & $1 \cdot 7$ & $1 \cdot 5$ \\
\hline Sodium bicarbonate & $0 \cdot 5$ & & \\
\hline Calcium carbonate & & $1 \cdot 6$ & \\
\hline Sodium chloride & $0 \cdot 2$ & $0 \cdot 7$ & \\
\hline Dicalcium phosphate & $0 \cdot 1$ & $1 \cdot 6$ & \\
\hline
\end{tabular}

west coasts and it is characterized by summers generally humid and warm, and winters fairly mild. These climatic conditions allow grazing all year round, and for this reason, pasture based systems have been traditional across the Atlantic Europe. Now, it is necessary to balance the production capacity of dairy cows with the use of grass in their diet without compromising milk production. This study has been directed to obtain milk with quality with low inputs, which makes farm exploitation based on pasture more profitable and sustainable. The aim of this study was to evaluate different strategies of limited grazing associated with TMR feeding on the FA profile of milk, feed intake and milk production.

\section{Materials and Methods}

Cows, diet and pasture. This work was undertaken in the spring of 2007, adhering to the standards of the European Union Animal Welfare Directive Number 86/609/EEC. Fifteen Holstein cows with $94 \pm 44$ days in milk were selected. The milk production of these cows was $34 \cdot 8 \pm 6 \cdot 8 \mathrm{l} / \mathrm{d}$ in the month prior to the start of the experiment. TMR was formulated according to NRC (2001) requirements for dairy cattle (Table 1). Additionally, two concentrates, A and B, were distributed as energetic supplements in an automatic feeder. Concentrate $A$ was offered at $2 \cdot 0 \mathrm{~kg} / \mathrm{d}$ per cow and concentrate B adjusted to $0.5 \mathrm{~kg} / \mathrm{l}$ of milk produced above $30 \mathrm{l} / \mathrm{d}$. Six 1.5 ha paddocks with a wide range of grasses (Agrostis tenuis, Dactylis glomerata, Lolium perenne), legumes (Trifolium repens, Viccia cracca) and other species provided the grazing area. Water was always available.
Experimental design. The animals were randomly assigned to three treatment sequences in a changeover design. Each trial period lasted 21 days, including 14 for adaptation and seven for data collection. The treatments were: 1 ) $12 \mathrm{~h}$ grazing (TMR12; $07 \cdot 30 \mathrm{~h}$ to $19 \cdot 30 \mathrm{~h}$ ) plus TMR; 2 ) $6 \mathrm{~h}$ grazing (TMR06; $12.30 \mathrm{~h}$ to $18.30 \mathrm{~h}$ ) plus TMR; and 3) no grazing time (TMR00) plus TMR. The TMR was offered ad libitum indoors in all treatments. Two adjoining paddocks were used in each experimental period, one for the adaptation stage, the other for the data collection stage. Both paddocks were divided into two plots by mobile electric fences, corresponding to the TMR06 and TMR12 treatments. On the day prior to the start of the trial, pasture yield and dry matter yield were measured to determine pasture availability and to set the grazing area of the paddocks (on the basis of herbage yield) according to the grazing time permitted. All cows were weighed on the first and last day of each period after morning milking. All were milked twice daily from 07:00-08:00 $\mathrm{h}$ and 19:00-20:00 h. After morning milking, the TMR12 cows were moved to their corresponding plot, where they stayed until evening milking. The TMR06 cows remained indoors until 12:30 h, and were then moved to their corresponding plot until evening milking. The TMR00 cows were kept indoors throughout the day.

The TMR intake of individual animals was recorded using a computerised system (Bach et al. 2004). TMR refusals were removed and weighed daily. Herbage intake in the TMR06 and TMR12 treatments were estimated using NRC prediction equations (Macoon et al. 2003). Briefly, energy requirements were recorded as net energy (NE $\mathrm{Mcal} / \mathrm{d})$ requirements for maintenance, lactation, body weight changes, walking and grazing. The NE from pasture intake was estimated as total NE requirements minus the NE supplied by the TMR and concentrate intakes.

Sample collection and analysis. TMR samples and orts were taken daily during the measurement period. Concentrates and pasture were sampled at the beginning of each trial period. TMR and forage samples were dried $\left(60{ }^{\circ} \mathrm{C}, 24 \mathrm{~h}\right)$ and ground $(0.75 \mathrm{~mm})$; concentrate samples were ground through a $1 \mathrm{~mm}$ screen. Dry matter (DM), ash, crude protein $(\mathrm{CP})$, ether extract and starch were determined by near infrared spectroscopy (NIRS; FOSS NIRSystem 5000). Neutral and acid detergent fibres (NDF, ADF) were analysed as described by Van Soest et al. (1991). Calcium was determined by AA spectrophotometry (Perkin Elmer 3030B) and phosphorus by UV-VIS spectrophotometry (Perkin Elmer 235 ). The FA content of the feeds was analysed according to Sukhija \& Palmquist (1988) with the modifications of Palmquist \& Jenkins (2003). The esterification of FA was performed using hexane and $10 \%$ methanolic $\mathrm{HCl}$ as follows: heating at $70{ }^{\circ} \mathrm{C}$ in a water bath for $2 \mathrm{~h}$, cooling and adding $2 \mathrm{ml}$ of hexane and $5 \mathrm{ml}$ of $6 \% \mathrm{~K}_{2} \mathrm{CO}_{3}$, and centrifuging for $5 \mathrm{~min}$ at $500 \mathrm{~g}$. 
Table 2. Chemical compositions ( $\%$ on DM) and fatty acid profiles of the total mixed ration (TMR), concentrates and pasture in the different trial periods

Values are means for $n=3$

\begin{tabular}{|c|c|c|c|c|c|c|c|c|}
\hline & \multirow[b]{2}{*}{ TMR } & \multicolumn{2}{|c|}{ Concentrates } & \multicolumn{3}{|c|}{ Pasture } & \multirow[b]{2}{*}{ SEM } & \multirow{2}{*}{$\begin{array}{l}P \text {-value } \\
\text { Pasture }\end{array}$} \\
\hline & & A & B & Period 1 & Period 2 & Period 3 & & \\
\hline Dry matter & $48 \cdot 2$ & $88 \cdot 5$ & $88 \cdot 7$ & $14 \cdot 7^{b}$ & $13 \cdot 6^{\mathrm{c}}$ & $15 \cdot 9^{\mathrm{a}}$ & $0 \cdot 127$ & $* *$ \\
\hline Organic matter & $92 \cdot 3$ & $91 \cdot 3$ & $92 \cdot 4$ & $90 \cdot 3^{\mathrm{ab}}$ & $89 \cdot 5^{b}$ & $91 \cdot 1^{\mathrm{a}}$ & $0 \cdot 165$ & $*$ \\
\hline Crude protein & $14 \cdot 9$ & $18 \cdot 1$ & $22 \cdot 2$ & $18 \cdot 4^{\mathrm{b}}$ & $21 \cdot 6^{\mathrm{a}}$ & $15 \cdot 3^{\mathrm{c}}$ & $0 \cdot 305$ & $* *$ \\
\hline Neutral detergent fibre & $46 \cdot 1$ & $18 \cdot 7$ & $14 \cdot 5$ & $40 \cdot 1^{\mathrm{a}}$ & $41 \cdot 9^{\mathrm{a}}$ & $35 \cdot 4^{\mathrm{b}}$ & $0 \cdot 324$ & $* *$ \\
\hline Acid detergent fibre & $22 \cdot 7$ & $9 \cdot 25$ & $5 \cdot 59$ & $20 \cdot 7^{b}$ & $22 \cdot 5^{\mathrm{a}}$ & $17 \cdot 4^{\mathrm{c}}$ & $0 \cdot 191$ & $* *$ \\
\hline Ether extract & $4 \cdot 52$ & $4 \cdot 53$ & $4 \cdot 43$ & $2 \cdot 83^{b}$ & $3 \cdot 17^{\mathrm{a}}$ & $3 \cdot 15^{a}$ & $0 \cdot 029$ & $* *$ \\
\hline Starch & $17 \cdot 4$ & $39 \cdot 9$ & $42 \cdot 7$ & $\mathrm{NA} \uparrow$ & NA & NA & & \\
\hline Calcium & $0 \cdot 77$ & 0.49 & $0 \cdot 52$ & $0.95^{a}$ & $1 \cdot 06^{\mathrm{a}}$ & $0 \cdot 47^{\mathrm{b}}$ & $0 \cdot 038$ & $* *$ \\
\hline Phosphorus & $0 \cdot 34$ & $0 \cdot 80$ & $1 \cdot 54$ & $0 \cdot 40$ & $0 \cdot 41$ & $0 \cdot 38$ & $0 \cdot 017$ & NSt \\
\hline $\mathrm{NE}_{\mathrm{I}}(\mathrm{Mcal} / \mathrm{kg} \mathrm{DM})$ & $1 \cdot 95$ & $1 \cdot 91$ & $1 \cdot 94$ & $1 \cdot 68$ & $1 \cdot 79$ & $1 \cdot 76$ & $0 \cdot 005$ & $* *$ \\
\hline \multicolumn{9}{|l|}{ Fatty acids (g/100 g FA) } \\
\hline C6:0 & $1 \cdot 60$ & $1 \cdot 01$ & $2 \cdot 59$ & ND & ND & ND & & \\
\hline C12:0 & ND§ & $5 \cdot 97$ & ND & ND & ND & ND & & \\
\hline C14:0 & ND & $1 \cdot 51$ & ND & ND & ND & ND & & \\
\hline C16:0 & $41 \cdot 6$ & $40 \cdot 6$ & $48 \cdot 9$ & $24 \cdot 2$ & $23 \cdot 9$ & $23 \cdot 2$ & 0.536 & NS \\
\hline C16: 1 & ND & ND & ND & 0.99 & $1 \cdot 80$ & $1 \cdot 14$ & $0 \cdot 165$ & NS \\
\hline C18:0 & $3 \cdot 33$ & $3 \cdot 42$ & $4 \cdot 03$ & $0 \cdot 61$ & $0 \cdot 48$ & $0 \cdot 82$ & $0 \cdot 293$ & NS \\
\hline C18: 1 & $28 \cdot 0$ & $25 \cdot 5$ & $30 \cdot 6$ & $1 \cdot 72^{b}$ & $1 \cdot 83^{b}$ & $3 \cdot 73^{\mathrm{a}}$ & $0 \cdot 260$ & $*$ \\
\hline $\mathrm{C} 18: 2$ & $24 \cdot 0$ & $21 \cdot 6$ & $13 \cdot 9$ & $14 \cdot 9^{\mathrm{b}}$ & $16 \cdot 2^{\mathrm{ab}}$ & $17 \cdot 7^{\mathrm{a}}$ & $0 \cdot 363$ & * \\
\hline C18: 3 & $1 \cdot 47$ & $0 \cdot 40$ & $0 \cdot 01$ & $57 \cdot 2$ & $56 \cdot 5$ & $53 \cdot 1$ & $1 \cdot 041$ & NS \\
\hline C20: 0 & ND & ND & ND & $0 \cdot 31$ & $0 \cdot 21$ & $0 \cdot 16$ & 0.035 & NS \\
\hline
\end{tabular}

Milk production was measured and the milk sampled daily at both milking times over the seven data collection days of each trial period. Milk samples were analysed for fat and protein contents (MilkoScan FT 6000). For milk FA analysis, the fat was isolated as described by Feng et al. (2004) and transesterified as described by Christie (1982) with the modifications of Chouinard et al. (1999). Two millilitres of hexane were added to $40 \mathrm{mg}$ milk fat. This was then added to $40 \mu \mathrm{l}$ sodium methylate in methanol and incubated at room temperature for 10 min before adding $60 \mu \mathrm{l}$ of a solution of $1 \mathrm{~g}$ oxalic acid in $30 \mathrm{ml}$ diethyl ether. These samples were then centrifuged for $5 \mathrm{~min}$ at $2400 \mathrm{~g}$ at $5{ }^{\circ} \mathrm{C}$. FA methyl esters were determined by gasliquid chromatography (Varian 4000 GC/MS, Inc. Palo Alto, CA, USA) in both milk and feed samples. Methyl esters were separated using a $100 \mathrm{~m} \times 0 \cdot 25 \mathrm{~mm}$ i.d. fused silica capillary column (CP-Sil 88 Varian). Individual FA peaks were identified by comparison of their retention times and mass spectra with those of pure methyl ester standards (Matreya Inc., PA.; Sigma-Aldrich Inc.).

Statistical analysis. Differences in the chemical composition of the pasture between trial periods were examined using the GLM procedure (SAS, 1999), recording the effect of period and the residual error. Feed intake and milk data were analysed using the GLM procedure (SAS, 1999) according to the model: $Y_{i j k}=\mu+A_{i}+P_{j}+T_{k}+E_{i j k}$, where $Y_{i j k}=$ the dependent variable, $\mu=$ the overall mean, $A_{i}=$ the effect of treatment, $P_{j}=$ the period, $T_{k}=$ the effect of the animal, and $E_{i j k}=$ the residual error. Means were separated using the Tukey test.

\section{Results}

Chemical composition of feedstuffs and pasture. Table 2 shows the chemical compositions and FA profiles of the TMR, concentrates and herbage for each trial period. No differences were seen between the trial periods with respect to the nutritive values of the TMR or concentrates. The chemical composition of the pasture, however, changed over the course of the experiment. During trial period 3, the pasture showed its lowest NDF and ADF contents, while the lowest DM and organic matter levels and the highest CP levels were seen during trial period 2 . Nearly $95 \%$ of the FA of the TMR and both concentrates was made up of palmitic (C16:0), oleic (C18:1) and 
Table 3. Body weight, dry matter (DMI) and FA intake for the three treatments

\begin{tabular}{|c|c|c|c|c|c|}
\hline \multicolumn{6}{|c|}{$\begin{array}{c}\text { Values are means for } n=15 \text { for body weight values, } n=105 \text { for the other } \\
\text { variables }\end{array}$} \\
\hline & TMR00 & TMR06 & TMR12 & SEM & $P$-value \\
\hline \multicolumn{6}{|l|}{ Body weight (kg) } \\
\hline Initial & 605 & 610 & 616 & $12 \cdot 5$ & NS \\
\hline Final & 607 & 609 & 618 & $13 \cdot 2$ & NS \\
\hline \multicolumn{6}{|l|}{ DMI (kg/d) } \\
\hline TMR & $19 \cdot 62^{\mathrm{a}}$ & $15 \cdot 15^{\mathrm{b}}$ & $11 \cdot 32^{\mathrm{c}}$ & $0 \cdot 446$ & $* *$ \\
\hline Concentrate A & $1 \cdot 71$ & $1 \cdot 73$ & $1 \cdot 72$ & 0.058 & NS \\
\hline Concentrate B & $1 \cdot 36$ & $1 \cdot 38$ & $1 \cdot 39$ & $0 \cdot 045$ & NS \\
\hline Pasture & $0 \cdot 0^{\mathrm{c}}$ & $5 \cdot 00^{b}$ & $8 \cdot 56^{\mathrm{a}}$ & 0.013 & $* * *$ \\
\hline Total & $22 \cdot 70$ & $23 \cdot 26$ & $23 \cdot 00$ & $0 \cdot 487$ & NS \\
\hline \multicolumn{6}{|l|}{$\mathrm{FA}(\mathrm{g} / \mathrm{d})$} \\
\hline $\mathrm{C} 6: 0$ & $13 \cdot 5^{\mathrm{a}}$ & $10 \cdot 8^{b}$ & $8 \cdot 7^{\mathrm{c}}$ & $0 \cdot 327$ & $* * *$ \\
\hline C12:0 & $3 \cdot 7$ & $3 \cdot 8$ & $3 \cdot 8$ & $0 \cdot 132$ & NS \\
\hline C14:0 & $0 \cdot 9$ & $0 \cdot 9$ & $0 \cdot 9$ & 0.033 & NS \\
\hline C16:0 & $347 \cdot 8^{a}$ & $304 \cdot 9^{\mathrm{b}}$ & $266 \cdot 1^{\mathrm{c}}$ & $7 \cdot 746$ & $* * *$ \\
\hline $\mathrm{C} 16: 1$ & $0 \cdot 0^{\mathrm{C}}$ & $1 \cdot 4^{b}$ & $2 \cdot 5^{\mathrm{a}}$ & 0.025 & $* * *$ \\
\hline C18:0 & $28 \cdot 1^{\mathrm{a}}$ & $23 \cdot 4^{b}$ & $19 \cdot 1^{\mathrm{c}}$ & $0 \cdot 628$ & $* * *$ \\
\hline $\mathrm{C} 18: 1$ & $231 \cdot 3^{\mathrm{a}}$ & $188 \cdot 3^{\mathrm{b}}$ & $151 \cdot 5^{\mathrm{c}}$ & $5 \cdot 165$ & $* * *$ \\
\hline $\mathrm{C} 18: 2$ & $190 \cdot 7^{\mathrm{a}}$ & $170 \cdot 6^{\mathrm{b}}$ & $149 \cdot 3^{c}$ & $4 \cdot 237$ & $* * *$ \\
\hline C18:3 & $10 \cdot 8^{c}$ & $67 \cdot 7^{\mathrm{b}}$ & $109 \cdot 2^{a}$ & 0.429 & $* * *$ \\
\hline$>\mathrm{C} 18$ & $0 \cdot 0^{\mathrm{C}}$ & $0 \cdot 2^{b}$ & $0 \cdot 4^{\mathrm{a}}$ & 0.003 & $* * *$ \\
\hline Total & $827^{a}$ & $771^{\mathrm{ab}}$ & $710^{\mathrm{b}}$ & $0 \cdot 180$ & $* * *$ \\
\hline
\end{tabular}

linoleic (C18:2) acids. The main FA of the pasture consumed were linolenic (C18:3), C16:0 and C18:2. Linear increases in $\mathrm{C} 18: 1$ and $\mathrm{C} 18: 2$ were observed over the course of the experiment.

Feed intake and body weight changes. Body weight changes ranged from -0.3 (TMR06) to $1.6 \mathrm{~kg}$ (TMR00), with no significant differences between treatments. The dry matter intake (DMI) associated with TMR decreased significantly when the time available for grazing increases (Table 3). No significant differences in the DMI associated with concentrate A or concentrate B were seen between any treatment. The pasture availability was 19.8 and $39.7 \mathrm{~kg} / \mathrm{d}$ per cow for the TMR06 and TMR12 treatments respectively. The DMI afforded by grazing, estimated as the difference between requirements and that supplemented by TMR and concentrates, was $60 \%$ higher in the TMR12 treatment than in the TMR06 treatment. However, no significant differences were seen between treatments with respect to total DMI.

The fat intake was significantly affected by the different treatments, ranging from to $0.71 \mathrm{~kg} / \mathrm{d}$ in the TMR12 treatment to $0.83 \mathrm{~kg} / \mathrm{d}$ in the TMR00 treatment $(P<0 \cdot 01)$. In fact, individual FA intake was different between treatments, except for lauric acid (C12:0), and myristic acid (C14:0). The TMR00 treatment was associated with higher
Table 4. Milk production, composition and FA profile for the three treatments

\begin{tabular}{|c|c|c|c|c|c|}
\hline \multicolumn{6}{|c|}{ Values are means for $n=105$} \\
\hline & TMR00 & TMR06 & TMR12 & SEM & $P$-value \\
\hline $\begin{array}{l}\text { Milk production } \\
(\mathrm{kg} / \mathrm{d})\end{array}$ & $34 \cdot 6$ & $35 \cdot 4$ & $33 \cdot 6$ & $0 \cdot 620$ & NS \\
\hline \multicolumn{6}{|l|}{ Composition (g/kg) } \\
\hline Fat & $38 \cdot 2^{\mathrm{ab}}$ & $38 \cdot 8^{\mathrm{a}}$ & $36 \cdot 2^{b}$ & $0 \cdot 612$ & $*$ \\
\hline Protein & $30 \cdot 2$ & $30 \cdot 4$ & $30 \cdot 6$ & $0 \cdot 175$ & NS \\
\hline \multicolumn{6}{|l|}{ Yield (kg/d) } \\
\hline Fat & $1 \cdot 31^{\mathrm{ab}}$ & $1 \cdot 39^{a}$ & $1 \cdot 23^{\mathrm{b}}$ & 0.037 & $*$ \\
\hline Protein & $1 \cdot 04$ & $1 \cdot 06$ & $1 \cdot 02$ & $0 \cdot 018$ & NS \\
\hline \multicolumn{6}{|l|}{$\mathrm{FA}(\mathrm{g} / 100 \mathrm{~g} \mathrm{FA})$} \\
\hline C6:0 & $2 \cdot 89$ & $2 \cdot 83$ & $2 \cdot 99$ & $0 \cdot 079$ & NS \\
\hline $\mathrm{C} 8: 0$ & $0 \cdot 88$ & $1 \cdot 02$ & $1 \cdot 00$ & $0 \cdot 063$ & NS \\
\hline C10:0 & $2 \cdot 79$ & $2 \cdot 94$ & $3 \cdot 17$ & $0 \cdot 134$ & NS \\
\hline C12:0 & $2 \cdot 28$ & $2 \cdot 40$ & $2 \cdot 52$ & $0 \cdot 195$ & NS \\
\hline Total short-chain & $8 \cdot 85$ & $9 \cdot 20$ & $9 \cdot 67$ & $0 \cdot 422$ & NS \\
\hline C14:0 & $12 \cdot 1$ & $12 \cdot 2$ & $12 \cdot 3$ & $0 \cdot 154$ & NS \\
\hline C14: 1 c9 & $0 \cdot 39$ & $0 \cdot 30$ & $0 \cdot 34$ & $0 \cdot 055$ & NS \\
\hline $\mathrm{C} 16: 0$ & $38 \cdot 9^{a}$ & $36 \cdot 8^{\mathrm{ab}}$ & $35 \cdot 1^{\mathrm{b}}$ & 0.639 & $* *$ \\
\hline C16: 1 c9 & $1 \cdot 30^{\mathrm{a}}$ & $1 \cdot 00^{\mathrm{b}}$ & $1 \cdot 13^{b}$ & $0 \cdot 063$ & $* *$ \\
\hline $\begin{array}{l}\text { Total medium- } \\
\text { chain }\end{array}$ & $52 \cdot 7^{\mathrm{a}}$ & $50 \cdot 3^{b}$ & $48 \cdot 9^{\mathrm{b}}$ & $0 \cdot 614$ & $* *$ \\
\hline C18:0 & $11 \cdot 5$ & $12 \cdot 1$ & $12 \cdot 2$ & $0 \cdot 248$ & NS \\
\hline C18: 1 c9 & $21 \cdot 7$ & $21 \cdot 3$ & $21 \cdot 9$ & $0 \cdot 306$ & NS \\
\hline C18: 1 t11 (VA) & $2 \cdot 26^{\mathrm{b}}$ & $4 \cdot 22^{\mathrm{a}}$ & $4 \cdot 09^{a}$ & $0 \cdot 187$ & $* *$ \\
\hline $\mathrm{C} 18: 2$ & $2 \cdot 18^{\mathrm{a}}$ & $1 \cdot 71^{\mathrm{b}}$ & $1 \cdot 72^{\mathrm{b}}$ & $0 \cdot 078$ & $* *$ \\
\hline $\begin{array}{l}\text { C18:2 c9 t11 } \\
\text { (CLA) }\end{array}$ & $0 \cdot 30^{\mathrm{C}}$ & $0 \cdot 42^{b}$ & $0 \cdot 60^{\mathrm{a}}$ & $0 \cdot 023$ & $* *$ \\
\hline $\mathrm{C} 18: 3$ & $0 \cdot 19^{c}$ & $0 \cdot 36^{\mathrm{b}}$ & $0 \cdot 52^{\mathrm{a}}$ & $0 \cdot 019$ & $* *$ \\
\hline Others & $0 \cdot 38$ & $0 \cdot 39$ & $0 \cdot 37$ & $0 \cdot 018$ & NS \\
\hline Total long-chain & $38 \cdot 5^{\mathrm{b}}$ & $40 \cdot 5^{a}$ & $41 \cdot 4^{\mathrm{a}}$ & $0 \cdot 501$ & $* *$ \\
\hline SFA & $71 \cdot 4^{\mathrm{a}}$ & $70 \cdot 5^{\mathrm{ab}}$ & $69 \cdot 4^{b}$ & $0 \cdot 369$ & $* *$ \\
\hline UFA & $28 \cdot 7^{\mathrm{b}}$ & $29 \cdot 6^{\mathrm{ab}}$ & $30 \cdot 7^{\mathrm{a}}$ & $0 \cdot 372$ & $* *$ \\
\hline MUFA & $25 \cdot 7^{b}$ & $26 \cdot 9^{\mathrm{ab}}$ & $27 \cdot 6^{\mathrm{a}}$ & $0 \cdot 355$ & $* *$ \\
\hline PUFA & $2 \cdot 93^{\mathrm{ab}}$ & $2 \cdot 75^{\mathrm{b}}$ & $3 \cdot 09^{\mathrm{a}}$ & $0 \cdot 058$ & $* *$ \\
\hline
\end{tabular}

intakes of $\mathrm{C} 6: 0, \mathrm{C} 16: 0, \mathrm{C} 18: 0, \mathrm{C} 18: 1$ and $\mathrm{C} 18: 2$ than either of the grazing treatments; these intakes decreased progressively as grazing time increased. The $\mathrm{C} 18: 3$ intake was directly related to its herbage content.

Milk production and milk composition. Table 4 shows the milk yield and composition results. No differences were seen between treatments with respect to milk production, milk protein content or protein yield. The milk fat content of the TMR12 milk was significantly lower than that of the TMR00 or TMR06 milk. This explains the low fat yield of the TMR12 milk.

Milk fatty acids. No significant differences were seen between treatments with respect to the short-chain FA content of the different milks. The medium chain FA content 
was highest in the TMR00 milk since the C16:0 and palmitoleic acid (C16:1) content decreased as grazing time increased. The long-chain FA content was higher in the TMR06 and TMR12 milk than in the TMR00 milk, a consequence of the formers' high VA (C18:1 t11), CLA (C18:2 c9 t11) and C18:3 contents. The VA content of the TMR06 and TMR12 milk was twice that of the TMR00 milk, with no significant difference between the TMR06 and TMR12 milk. The CLA content was higher in the milk produced in the grazing treatments than that produced in the TMR00 treatment. Indeed, the TMR12 milk had a $50 \%$ and $30 \%$ higher CLA content than the TMR00 and TMR06 milk respectively. In addition, the C18:3 content was $32 \%$ higher $(P<0 \cdot 01)$ than in the TMR06 milk, and nearly three times that of the TMR00 milk. However, the grazing treatments led to a reduction in milk C18:2 content compared with the TMR00 treatment. The proportion of unsaturated FA (UFA), including monounsaturated FA (MUFA) and PUFA, was higher in the TMR12 milk than in than TMR00 milk. The TMR06 milk showed an intermediate value.

\section{Discussion}

In the present work, the different treatments had no effect on milk production. This agrees with that reported by other authors who examined the feeding of cows with TMR plus the grazing of pasture (Loor et al. 2003) or winter oats (Schroeder et al. 2003) grazing. This absence of any difference in milk yield might be explained by the adequate net energy intake of the grazing cows, confirmed by the absence of variation in live weight. The reduction in milk fat content seen with the TMR12 treatment has been reported by other authors (Loor et al. 2003; Elgersma et al. 2004) after switching cows from TMR to fresh forage.

As seen in the present work, Schroeder et al. (2003) reported a lower $\mathrm{C} 16: 0$ and a higher $\mathrm{C} 18: 1$ content in the milk of grazing cows than in that of cows fed TMR. Similarly, Elgersma et al. (2004) reported that switching cows from fresh pasture to TMR during the winter increased the C16:0 content of their milk from 22.6 to $34 \cdot 8 \mathrm{~g} / 100 \mathrm{~g}$ FA. Ward et al. (2003) observed lower concentrations of $\mathrm{C} 16: 0$ in milk when increasing the DMI provided by fresh pasture from 50 to $80 \%$. In the present study, the greater intake of C16:0 in the TMR00 treatment than in the TMR06 or TMR12 treatment might explain the slightly higher C16:1 content of the TMR00 milk; $\mathrm{C} 16: 1$ can be produced through the desaturation of C16:0 via the action of delta-9 desaturase (Peterson et al. 2002).

The low proportion of $\mathrm{C} 18: 2$ in milk from the TMR12 cows can be explained by the fall in $\mathrm{C} 18: 2$ intake and by its hydrogenation in the rumen. The latter could have contributed to an increase in the VA, CLA and stearic acid contents of the milk as a result of their synthesis from C18:2 in the rumen. Some authors have reported similar results when feeding cows fresh forage (Ferlay et al. 2006), when grazing cattle (Bargo et al. 2006), and when feeding with fish and plant oils (AbuGhazaleh et al. 2007).

In this study, the pasture intake reduced the proportion of SFA and increased that of UFA (mainly MUFA) in the milk. This might be explained by the higher intake of C18:2 and C18:3 in fresh forage and their biohydrogenation in the rumen. With a pattern similar to that seen in the present work, Bargo et al. (2006) reported high intakes of $\mathrm{C} 18: 3$ and $\mathrm{C} 18: 2$ in cows feeding on pasture. Bauman et al. (2000) showed that ruminal lipolysis and free FA biohydrogenation led to drastic reductions $(70-90 \%)$ in dietary PUFA via their transformation into trans-isomers of MUFA (especially VA) or SFA (mainly stearic acid).

The synthesis of CLA is an important factor to consider in nutritional strategies involving high proportions of fresh forage since it provides PUFA, of which C18:3 makes up some $50-75 \%$ (Elgersma et al. 2005). The supplementation of TMR with pasture provides additional C18:2, a direct precursor of CLA and VA, while C18:3 increases the proportion of VA in the rumen. In turn, VA is an important substrate that can be converted to CLA in the mammary gland via the action of delta-9 desaturase (Griinari et al. 2000). This may also explain the high VA, CLA and C18: 3 contents in the TMR12 milk. However, a slightly higher VA concentration was seen in the TMR06 milk than in the TMR12 milk, despite the cows of the latter treatment having $6 \mathrm{~h}$ more grazing time and therefore enjoying greater pasture availability and $\mathrm{C} 18: 3$ intake. The TMR12 treatment should have provided an even higher C18:3 and C18:2 intake, leading to the highest levels of VA and CLA. However, the VA might have been more effectively absorbed and desaturated in the mammary tissue to produce CLA, thus explaining the higher concentration of CLA and slightly lower concentration of VA than seen in the TMR06 milk.

The relationships between forage quality and the meadow effect in each trial period are difficult to explain. The C18:3 concentration is higher in grass than in legumes. Moreover, the lipids of forage are located in the leaf chloroplasts; a high proportion of leaves in the diet might therefore lead to a high intake of $\mathrm{C} 18: 3$. The paddocks used in the present study, although adjacent and with similar botanical compositions, differences in terms of species proportions or plant maturity might therefore have influenced the C18:1 and C18:2 contents of the forage (Elgersma et al. 2005).

In these climatic conditions, grazing is allowed all year round. This fact allows savings in the cost of food in the barn, which could provide increased profitability to dairy farms. Moreover, the results show that the use the grass does not reduce milk yield, and fat is healthier also, which could lead to an increase in value added of milk produced in this system. 
In conclusion, the intake of fresh herbage through grazing as a supplement to TMR could be used as a strategy for modifying the FA profile of milk made by cows living under oceanic climatic conditions. Feeding strategies based on grazing could lead to substantial increases in MUFA in milk. Six hours of grazing leads to no reduction in the milk yield, and saves $3.5 \mathrm{~kg}$ of TMR/d per cow. Twelve hours grazing reduces the DMI associated with TMR without affecting milk yield, but provides milk with higher proportions of CLA and C18:3. Improving the FA profile of milk by grazing should be considered in strategies designed to produce healthier milk.

This work was supported by Spanish projects PCTI-PC06-006 and INIA-RTA2007-0058-C02. Mr. Morales-Almaráz was financed by CONACYT-México.

\section{References}

AbuGhazaleh AA, Felton DO \& Ibrahim SA 2007 Milk conjugated linoleic acid response to fish oil and sunflower oil supplementation to dairy cows managed under two feeding systems. Journal of Dairy Science 90 4763-4769

Bach A, Iglesias C \& Busto I 2004 Technical note: A computerized system for monitoring feeding behaviour and individual feed intake of dairy cattle. Journal of Dairy Science 87 4207-4209

Bargo F, Delahoy JE, Schroeder GF \& Muller LD 2006 Milk fatty acid composition of dairy cows grazing at two pasture allowances and supplemented with different levels and sources of concentrate. Animal Feed Science and Technology 125 17-31

Bauman DE, Baumgard LH, Corl BA \& Griinari JM 2000 Biosynthesis of conjugated linoleic acid in ruminants. Journal of Animal Science $\mathbf{7 7}$ $1-15$

Christie WW 1982 A simple procedure for rapid transmethylation of glycerolipids and cholesterol esteres. Journal of Lipid Research $\mathbf{2 3}$ 1072-1075

Chouinard PY, Louise Corneau, Barbano DM, Metzger LE \& Bauman DE 1999 Conjugated linoleic acids alter milk fatty acid composition and inhibit milk fat secretion in dairy cows. Journal of Nutrition 129 1579-1584

Dewhurst RJ, Shingfield KJ, Lee MRF \& Scollan ND 2006 Increasing the concentrations of beneficial polyunsaturated fatty acids in milk produced by dairy cows in high-forage systems. Animal Feed Science and Technology 131 168-206

Elgersma A, Ellen G, Van der Horst H, Mouse BG, Boer H \& Tamminga S 2004 Quick changes in milk fat composition after transition from fresh grass to a silage diet. Animal Feed Science and Technology 117 $13-27$

Elgersma A, Maudet P, Witkowska IM \& Wever AC 2005 Effects of nitrogen fertilisation and regrowth period on fatty acid concentrations in perennial ryegrass (Lolium perenne L.). Annals of Applied Biology 147 $145-152$
Elgersma A, Tamminga S \& Ellen G 2006 Modifying milk composition through forage. Animal Feed Science and Technology 131 207-225

Feng S, Lock AL \& Garnsworthy PC 2004 Technical note: A rapid lipid separation method for determining fatty acid composition of milk. Journal of Dairy Science 87 3785-3788

Ferlay A, Martin B, Pradel Ph, Coulon JB \& Chilliard Y 2006 Influence of grass-based diets on milk fatty acid composition and milk lipolytic system in tarentaise and montbéliarde cow breeds. Journal of Dairy Science 89 4026-4041

Fontaneli RS, Sollenberger LE, Littell RC \& Staples CR 2005 Performance of Lactating Dairy Cows Managed on Pasture-Based or in Freestall Barn-Feeding Systems. Journal of Dairy Science 88 1264-1276

Griinari JM, Corl BA, Lacy SH, Chouniard PY, Nurmela KVV \& Bauman DE 2000 Conjugated linoleic acid is synthesized endogenously in lactating cows by delta 9-desaturase. Journal of Nutrition 130 2285-2291

Kay JK, Roche JR, Kolver ES, Thomson NA \& Baumgard LH 2005 A comparison between feeding systems (pasture and TMR) and the effect of vitamin E supplementation on plasma and milk fatty acid profiles in dairy cows. Journal of Dairy Research 72 322-332

Loor JJ, Soriano FD, Herbein JH \& Polan CE 2003 Grazing allowance after the morning or afternoon milking for lactating cows fed a total mixed ration (TMR) enhances trans11-18:1 and cis9,trans11-18:2 (rumenic acid) in milk fat to different extents. Animal Feed Science and Technology 109 105-119

Macoon B, Sollenberger LE, Moore JE, Staples CR, Fike JH \& Portier KM 2003 Comparison of three techniques for estimating the forage intake of lactating dairy cows on pasture. Journal of Animal Science $\mathbf{8 1}$ 2357-2366

National Research Council 2001 Nutrient Requirements of Dairy Cattle. 7th rev. ed. National Academy Press, Washington, DC

Palmquist DL \& Jenkins TC 2003 Challanges with fats and fatty acid methods. Journal of Animal Science 81 3250-3254

Peterson DG, Kelsey JA \& Bauman DE 2002 Analysis of variation in cis9, trans11 conjugated linoleic acid (CLA) in milk fat of dairy cows. Journal of Dairy Science 85 2164-2172

SAS 1999 SAS/STATTM. User's Guide. Statistical Analysis System Inst, Cary, NC

Schroeder GF, Delahoy JE, Vidaurret I, Bargo F, Gagliostro GA \& Muller LD 2003 Milk fatty acid composition of cows fed a total mixed ration or pasture plus concentrates replacing corn with fat. Journal of Dairy Science 86 3237-3248

Sukhija PS \& Palmquist DL 1988 Rapid method for determination of total fatty acid content and composition of feedstuffs and feces. Journal of Agricultural and Food Chemistry 36 1202-1206

Van Soest PJ, Robertson JB \& Lewis BA 1991 Methods of dietary fiber, neutral detergent fiber and nonstarch polysaccharides in relation to animal nutrition. Journal of Dairy Science 74 3583-3597

Vibart RE, Fellner V, Burns JC, Huntington GB \& Green Jr JT 2008 Performance of lactating dairy cows fed varying levels of total mixed ration and pasture. Journal of Dairy Research 75 471-480

Ward AT, Wittenberg KM, Froebe HM, Przybylski R \& Malcolmson L 2003 Fresh forage and solin supplementation on conjugated linoleic acid levels in plasma and milk. Journal of Dairy Science $\mathbf{8 6}$ 1742-1750 